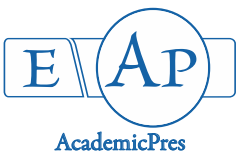

Sun W etal. (2021)

Notulae Scientia Biologicae

Volume 13, Issue 2, Article number 10881

DOI: $10.15835 / \mathrm{nsb} 13210881$

Review Article

\title{
Organic waste utilization and urban food waste composting strategies in China - A review
}

\section{Wenli SUN ${ }^{\text {la }}$, Mohamad H. SHAHRAJABIAN ${ }^{1 \mathrm{~b}}$, Qi CHENG ${ }^{1,2 *}$}

\author{
${ }^{I}$ Chinese Academy of Agricultural Sciences, Biotechnology Research Institute, Beijing 100081, \\ China;sunwenli@caas.cn; hesamshahrajabian@gmail.com \\ ${ }^{2}$ Hebei Agricultural University, College of Life Science, Baoding, Hebei, 071000, China; Global Alliance of HeBAU-CLS\&HeQiS \\ for BioAl-Manufacturing, Baoding, Hebei 071000, China; chengqi@caas.cn ('corresponding author) \\ ${ }^{a, b}$ These authors contributed equally to the work
}

\begin{abstract}
Food loss may occur in production, storage, transport, and processing, which are the stages of the value chain with the lowest returns. The current searching was done by the keywords in main indexing systems including PubMed/MEDLINE, Scopus, and Institute for Scientific Information Web of Science as well as the search engine of Google Scholar. The most important points challenging areas that represent opportunities for stakeholders to look into in China are, put in place suitable economic incentives to encourage restaurants to get more involved in the formal system, create a comprehensive regulation system to benefit all relevant stakeholders by clearly defining their respective roles and responsibilities, which is necessary for the proper functioning of the whole system. In China, the most important regulations, policies and plans are regulations on safety issues of food waste treatment, detailed countermeasures on organizing, educating, supervising, and inspecting the work on food waste reduction in China, and detailed plant for household waste collection and treatment, issued by Chinese government, state council, and ministry of environmental protection. Setting national goals, awareness-raising campaigns, strict and appropriate regulation, stakeholder engagement, biorefinery and food waste recycling to animal feed are important strategies for better waste management. The most important food waste management practices in China are source separation, animal feed, rendering, composting, co-digestion, anaerobic digestion, incineration, landfill, and etc. Understanding social factors influencing household behavior is utmost importance; public education and specific communication highly contribute to improve recycling.
\end{abstract}

Keywords: animal nutrition; food composting; food waste; organic waste

\section{Introduction}

Wastes fall in to five groups, ordinary wastes, medical (health care) wastes, special wastes, industrial wastes, and agricultural wastes. Clean technology can be implemented to minimize waste, and increasing productivity and reducing the unit cost of the products. One third of the food produced globally for human consumption is either lost or wasted every year which has a high potential of energy recovery (Jeevahan et al., 2018; Shahrajabian et al., 2019; Ilakovac et al., 2020). Inappropriate management of organic waste is the main 
cause of environmental pollution and nutrient loss in many countries, especially developing countries (Soleymani et al., 2016; Soleymani and Shahrajabian, 2017; Shahrajabian et al., 2017; Bekchanov and Mirzabaev, 2018; Shahrajabian et al., 2020; Sun et al., 2021a, b). Food loss means decrease in weight (dry matter) or quality (nutritional value) of food that was originally produced for human consumption, while food waste means food appropriate for human consumption being discarded, whether after it is left to spoil or kept beyond its expiry date. The loss of edible food and inedible food parts at the point of retail or consumer use is typically considered food waste, food that is lost in the stages between production and distribution, where, food may have spoiled as a result of production and processing technologies, is considered food loss. Three main objectives are preventing food waste from occurring in the first place, recover safe and nutritious food for people and food scraps for animals, and recycle energy and nutrients from the remaining, unavoidable food waste. The most important factors which may cause food loss and waste are human behavior and the incentives behind it such as consumer, employee and management decisions, time-limited biological reality of food-particularly fresh and unpackaged food, limited or lack of advanced technology, equipment, packaging, etc; risk perception and risk avoidance among businesses and consumers; and unintended consequences of regulation. Compost products application has a potential in the suppression of plant pathogens and green waste composting represents a promising approach in sustainable agriculture (Milinkovic et al., 2019). Composting is a natural process that stems through microbial succession, marking the degradation and stabilization of organic matter present in waste (Rastogi et al., 2020). Most municipal solid waste consists of biodegradable components, and the most abundant biological component is cellulose, followed by hemicelluloses and lignin (Donovan et al., 2010). The most important reasons for improving the recycling of municipal and industrial organic waste on agricultural land are benefits to crop production due to the recycling of organic matter and mineral nutrients and possible suppression of soil-borne pathogens, conservation of naturally available but limited supplies of nutrient resources and avoidance of alternative disposal methods which are environmentally damaging, expensive or limited by space (Schulz and Romheld, 1997). Composts are safer from an agricultural point of view than fresh wastes, because they contain a smaller amount of phytotoxic substances and organic matter is more stabilized than in fresh residues (Ayuso et al., 1996). Factors affecting the composting process are $\mathrm{C} / \mathrm{N}$ ratio, $\mathrm{pH}$, moisture content, aeration $/ \mathrm{O}_{2}$ supply, temperature, particle size, and bulking agents. Various methods are available for composting process, rotary drum is an efficient and decentralized composting technique which helps in proper mixing, aeration and produces stable and matured compost, while analytical hierarchy process is very popular and widely used decision-making method to solve the problems of various fields (Sharma and Yadav, 2018). As China has experienced double-digit economic growth in recent 30 years, more than 300 million people have moved into big cities, and the relationship between people and food, and food waste has changed. A significant portion of food waste ends up in landfills or incinerators without undergoing proper treatment or is illegally diverted into the informal system to feed livestock or produce cooking oil through practices that have resulted in serious food safety problems. China is currently trying to facilitate food waste harmless disposal and resource utilization by urban food waste management, but it is critical for government departments to take advantage of the informal regulation of the public and NGO, gradually reduce food waste treatment fee and maintain a reasonable regulation cost to increase urban food waste management and promoting food waste harmless disposal and resource utilization (Zhu et al., 2020). Factors contributing to food waste, effective cost/benefit food waste utilization methods, sustainability and environment considerations, and public acceptance are recognized as hurdles in preventing large-scale food waste processing (Ghosh et al., 2016). Food waste has not only incurred economic losses and negative environmental impact, but it also threatens China's agricultural capacity to deliver fresh, safe and affordable produce to its rising middle class and urbanites. Tremendous food waste also equates to a loss of resources such as water, seed, and labor, which are already considered scarce in China. Composting is divided into two categories, earthworm composting and microorganism composting. Through earthworm composting, food waste is utilized as earthworm feed for worm cultivation; both worms and worm castings being used as the soil conditioners or organic compost in agricultural activities. Through microorganism composting, food waste is 
decomposed and converted into microbial fertilizers rich in diverse nutrients that can improve soil quality and productivity. The aim of this mini-review is survey on organic waste, organic waste utilization in animal nutrition, urban food waste composting, and public awareness, especially in China.

\section{Organic Waste}

Organic wastes are increasingly becoming a valuable resource and have the potential to significantly spur the transition towards a sustainable and circular bioeconomy (Mahjoub and Domscheit, 2020). Organic waste diversion program participants are motivated by environmental concern (Pickering et al., 2020). Different types and sources of organic wastes are domestic or household waste, commercially produced organic waste, animal and human waste, and agricultural residue. Food waste most commonly refers to edible food products, which are intended for the purposes of human consumption, but have instead been discarded, lost, degraded or consumed by pests, and does not include the inedible or undesirable portions of foodstuffs. Food waste is considered as an obstacle to achieving food and nutrition security for the millions of undernourished around the world, and most societies attach an ethical and moral dimension to food waste. Food loss occurs in production, storage, transport, and processing, which are the stages of the value chain with the lowest returns. Organic waste biorefinery is a concept for waste management which can extract high value products from organic waste and technological, strategic and market constrains may affect implementation (Alibardi et al., 2020). Organic waste fertilization which might be an alternative for mineral fertilizers, promoted soil biochemical and microbial properties (Gryta et al., 2019). Composted organic waste has been proved to be a good amendment for soil productivity and agricultural sustainability while reducing nitrate leachate (Galsim et al., 2020). The objectives of composting can be stabilization, volume and mass reduction, drying, elimination of phytotoxic substances and undesired seed and plant parts, and sanitation. Some important wastes for composting are kitchen waste, biowaste, garden and green waste, garbage, feces of human, wastewater sludge (raw), wastewater sludge (anaerobic stabilized), dung of cattle, horses, sheep, pigs, liquid manure of cattle, pigs and chickens, beet leaves, straw, fresh bark, bark mulch, wood chips, leaves, reed, peat, paunch manure, grape marc, fruit marc, tobacco and paper, Organic waste management and bioenergy production are complementary to each other; while social, economic and environmental development are key indicators for sustainable waste management, nanotechnological based implications play a profound role in increasing bioenergy production (Dhanya et al., 2020). Solar composers offer a viable solution in rural areas lacking connection to municipal power supplies, and solar composting greenhouse has a high potentiality to transform organic waste into organic fertilizer (Lin et al., 2020). Sustainable energy from waste organic matters may mitigate climate changes, toxic gases and particle generation (Srivastava et al., 2020). The absence of source separation of organic municipal solid waste and the farmers' lack of awareness of compost's advantages as a substitute for conventional fertilizers are main reasons of the efficiency of composting organic wastes (Kan et al., 2010). Guo et al. (2021) reported that conventional treatment and recycling methods of organic solid waste contain inherent flaws, such as low efficiency, low accuracy, high cost, and potential environmental risks, and most studies have been focused on municipal solid waste management, followed by anaerobic digestion, thermal treatment, composting and landfill. Moldagulova et al. (2020) reported that thermotolerant microorganisms play an important role in the composting process of organic waste which are responsible for the degradation process of organic compounds owing to their enzymatic activity in the high-temperature phase of composting. Duan et al. (2020) found that biorefinery facing a big challenge in technical, financial and social awareness, and circular bioeconomy requires coordinated policy intervention in socioeconomic. Both aerobic and anaerobic digestion technology is sustainable approach for biorefinery (Wainaina et al., 2020). The adoption of anaerobic membrane bioreactors for organic solid waste management is important for the recovery of energy and highquality treated water (Inaba et al., 2020). Anaerobic digestion can represent a simple biorefinery producing both energy and polyhydroxyalkanoates (Papa et al., 2020). Composting of organic waste helps to ensure 
environmental sustainability, reduce greenhouse effects by mitigating the production of gases like methane, reduce the volume of wastes drastically and recalcitrant substances (Ayilara et al., 2020). The most important factors which influence the decomposition process of organic wastes are carbon to nitrogen $(\mathrm{C}: \mathrm{N})$ ratio, moisture content, temperature and oxygen (Salah and Hala, 2017). Fundamental types of composting aerobic and anaerobic are presented in Table 1.

Table 1. Fundamental types of composting aerobic and anaerobic

\begin{tabular}{|l|l|}
\hline \multicolumn{1}{|c|}{ Type } & \multicolumn{1}{c|}{ Key points } \\
\hline \multirow{4}{*}{ Aerobic composting } & $\begin{array}{l}\text { Composting is the decomposition of organic waste in the presence of oxygen (air); the process } \\
\text { includes } \mathrm{CO}_{2}, \mathrm{NH}_{3} \text {, water and heat. Composting requires the moisture contents around } 60- \\
70 \% \text { and carbon to nitrogen ratios of 30/1. Wood and paper provide an important source of } \\
\text { carbon, while sewage sludge and food waste provide to nitrogen to ensure and adequate supply } \\
\text { of oxygen at all times. Ventilation of waste is important. }\end{array}$ \\
\hline $\begin{array}{l}\text { Anaerobic } \\
\text { composting }\end{array}$ & $\begin{array}{l}\text { It is the decomposition of organic wastes in the absence of O2, the products being methane } \\
\left(\mathrm{CH}_{4}\right), \mathrm{CO}_{2}, \mathrm{NH}_{3} \text {, and trace amounts of other gases and organic acids. It was traditionally used } \\
\text { to compost animal manure and human sewage sludge which can be used for some municipal } \\
\text { solid waste and green waste. }\end{array}$ \\
\hline
\end{tabular}

\section{Urban Food Waste Composting}

Food waste has emerged as a key governance challenge in many countries (Brink, 1994; Warshawsky, 2020). It is considered as inherent part of the global food system, with significant environmental social and economic impacts (Boulet et al., 2019). Food waste serves as a valuable and sustainable resource, which can alleviate the environmental and health problems associated with organics in landfills. Cooperative solid waste composting may reduce environmental health concerns associated with agricultural wastes, while generating a value-assed soil amendment and reducing solid waste volume (Kelley et al., 1999). The overall benefits of $\$ 100 / \mathrm{Mg}$ for the Chicago case study suggest the financial feasibility of pursuing a city-wide decentralized composting strategy (Pai et al., 2019). The complexities in choosing appropriate assumptions, factors and datasets are important parameters for calculating food waste baseline amounts (Davies and Legg, 2018; Dusoruth et al., 2018). Anaerobic digestion is the main means of energy utilization which has the advantages of high benefit, and can be used for recycling clean energy. Anaerobic digestion includes batch system, continuous flow single-phase digestion system and continuous flow two-phase system. Composting is an effective fertilizer treatment technology for organic waste; aerobic composting has a high temperature, generally $50^{\circ} \mathrm{C}-65^{\circ} \mathrm{C}$, so it is also called high temperature composting, and this method can kill pathogenic bacteria to maximum extent and degrade organic matter rapidly; moreover, aerobic composting includes direct composting of fruit and vegetable waste and mixed landfill of fruit and vegetable wastes and feces. On-farm composting is viable option because of its tremendous benefits on soil quality and plant health which valorize underused biomass (Corato, 2020). Also, focusing of food packaging performance in food waste minimization is critical (Kakadellis and Harris, 2020). The most environmentally friend food waste conversion technology is composting after pre-treatment of high temperature, and the next most one is direct composting treatment which is followed by anaerobic co-digestion with sewage sludge, and the worst one is transforming food waste into bio-ethanol (Tseng and Chiueh, 2015).

Composting of food waste encounters a number of technical challenges, arising weak physical structure of food waste with weak porosity, high content of water, low carbon-to-nitrogen relation and fast hydrolysis and accumulation of organic acids during composting (Voberkova et al., 2020). Anaerobic digestion coupled with effective nutrient and energy recovery appears to be the preferred option to improve the overall sustainability of household food waste management in Amsterdam (Tonini et al., 2020). Kucbel et al. (2019) reported that composts household food waste has low stabilization of organic components. Nigussie et al. 
(2015) concluded that education, landownership, experience with compost and access to extension services may explain variation in compost demand. Improvement of separate collections of food market and municipal gardening wastes can provide specific clean waste streams of degradable materials to be managed separately from not separately collected municipal solid waste (Jara-Samaniego et al., 2015). The slow release nitrogen supplied by food waste composts is ideally suited for urban landscapes, where a moderate, consistent rate of plant growth is highly desirable (Sullivan et al., 1998). Slorach et al. (2020) concluded that anaerobic digestion is environmentally the most sustainable option with the lowest overall impact on the nexus, and incineration is the second-best option but has a greater impact on the health aspect than landfilling; moreover, landfilling has the greatest influence on the water aspect and the second highest overall impact on the nexus. Sullivan et al. (2003) reported that after 7 year, increased soil organic matter (both total soil $\mathrm{C}$ and $\mathrm{N}$ ) in the compost amended soil accounted for nearly $18 \%$ of compost- $\mathrm{C}$ and $33 \%$ of compost-N applied. Tucker and Farrelly (2016) concluded that individual or household-level changes of food waste are important and should be supported by both local body and state level legislation and initiatives. Mansfield and Mendes (2013) also emphasized on roles of local of government in food production, food processing, food distribution, food access and food waste management. The use of wood chips in composting increases the efficiency nutrient retention from food waste and in turn increases nutrient recycling in urban environments (Small et al., 2017). Sun et al. (2020) also concluded that food waste compost and wood waste biochar were effective bioretention filters for metal removal. The use of zeolite and perlite regulates the concentrations of ammonia and consequently the nitrate in the substrate of home composting of kitchen waste (Margaritis et al., 2018). Reasonable temperature, $\mathrm{pH}$, good mixing and small particle sizes are important factors for successful and productive anaerobic digestion process of food wastes (Leung and Wang 2016). Kaudal and Weatherley (2018) reported that addition of 10\% urban biochar to food waste accelerated the composting process. Mandpe et al. (2019) observed that combination of $80 \%$ organic waste and $20 \%$ fly ash showed better enzymatic activity. Pereira et al. (2018) that $\mathrm{CH}_{4}$ emissions are the major environmental aspects during organic urban waste composting, and composting stabilizes about $50 \%$ of the initial total $\mathrm{C}$ content.

Compost can be utilized as fertilizer and energy fuel, promoting circular economy, and optimizing composting process and composter can mitigate the environmental impacts (Liu et al., 2018; Chia et al., 2020). Pacilomyces lilacinus has protease activity and nematocidal ability which can convert food waste into nematocidal biofertilizer (Yu et al., 2015). Zhao et al. (2019) highlighted the necessity of location-suitable and urban-rural recycling nitrogen management strategies for reducing the risk of nitrogen emission from household food consumption in China. Guo et al. (2018) proposed the source-separation composting in situ with complete equipment, which may lead to obtaining high quality compost, and the odor $\left(\mathrm{H}_{2} \mathrm{~S}\right.$ and $\left.\mathrm{NH}_{3}\right)$ could be effectively controlled in the composting process. Lime addition as well as formation of struvite through the addition of magnesium and phosphorus salts may provide good $\mathrm{pH}$ buffering and reduce odor emission (Wang et al., 2018). It has reported that Chinese medicinal herbal residues are a good bulking agent of composting, and longer thermophilic phase was found in treatment 1:1:1 (Food waste: sawdust: Chinese medicinal herbal residues) (Zhou et al., 2018). Chinese medicinal herbal residue can be a potential bulking agent/co-substrate, and Chinese medicinal herbal residue-born active ingredients are the main cause of inhibition (Zhou et al., 2016). Chen et al. (2015) reported that heat treatment process did not significantly reduce the concentration of hazardous trace elements in food waste, but the separation process for solid and aqueous components, such as centrifugal dehydration, could reduce the risk considerably; they have concluded that combined with the separation technology for solid and liquid components, dry-heat treatment is superior to moist-heat treatment on the removal of external water-soluble ionic hazardous trace elements. The most important points challenging areas that represent opportunities for stakeholders to look into in China are, put in place suitable economic incentives to encourage restaurants to get more involved in the formal system, create a comprehensive regulation system to benefit all relevant stakeholders by clearly defining their respective roles and responsibilities, which is necessary for the proper functioning of the whole system, foster the development of companies specializing in different waste treatment technologies, which is a growing trend that will help 
achieve higher treatment efficiency at a lower cost, support and incentivize the development of a market which closes the loop and redeploys these wastes as new resources. In China, the most important regulations, policies and plans are regulations on safety issues of food waste treatment, detailed countermeasures on organizing, educating, supervising, and inspecting the work on food waste reduction in China, and detailed plant for household waste collection and treatment (a safe treatment rate of $80 \%$ in urban areas by 2015), issued by Chinese government, state council, and ministry of environmental protection ( $\mathrm{Li}$ et al., 2016). Guo et al. (2018) reported that during 10 days drum composting, the temperature of food waste experienced three classic phases including heating phase, thermophilic phase, and cooling phase, and the concentration of $\mathrm{H}_{2} \mathrm{~S}$ and $\mathrm{NH}_{3}$ in the effluent were as low as 0.0001 and $0.025 \mathrm{mg} / \mathrm{m}^{3}$ after biofiltering treatment, and after 20 days subsequent post-maturity, total content of $\mathrm{N}, \mathrm{P}$ and $\mathrm{K}$ in the food waste compost was as high as $11.66 \%$, and as for economical consideration, the average investment and energy consumption of the CPRM were as low as US\$ 61.5 and $50.0 \mathrm{kWh} / \mathrm{t}$. They have concluded that the successful case of the pilot scale plant showed the mode of source separation-composting in situ with composting in situ with complete equipment (CPEM) was feasible to realize the recycling of food waste. Possible strategies to prevent the food loss and waste (FLW) at different stages of food supply chains (FSC) were presented in Table 2.

Toledo et al. (2019) reported that co-composting of eggplant waste and sewage sludge had an important impact on odor concentration reduction. Palm waste can be managed by co-composting with sewage and agrifood sludge, but the use of date palm waste may increase the salt contents in the final composts (Vico et al., 2018; Doctor et al., 2020). The most important responsibilities of waste management in China are cleaning of streets, collection, transport, transfer, recycling, treatment, disposal, supervision, training, legislation and issuing of technical standards on pollution control, supervision, pollution control, enforcement, solid waste import/export, administration, legislation, planning and construction, technical standards, research, training, supervision, information collection, regulations on material recovery and material recovery (Wang and Nie, 2001).

\section{Organic Waste Utilization in Animal and Poultry Nutrition}

Not only in rural areas, but also in urban regions, China lacks advanced waste management facilities, waste management firms, and other institutions-effective, high-quality management systems like those in other developed countries (Rada et al., 2014; Ferreira et al., 2017; Ranieri et al., 2017). The most important food waste resources which have potential to convert to food waste to animal feed are household and catering food waste, kitchen and food factory waste, household and catering food waste, manufacturing food waste, retail food waste, compared banana chicken, lettuce, beef, bread waste (Takata et al., 2012; Tufvesson et al., 2013; Vandermeersch et al., 2014; Salemdeeb et al., 2017). Kazemi-Bonchenari et al. (2017) concluded that poultry slaughterhouse waste has a considerable amount of essential amino acids, which can be used in ruminant nutrition has a huge potential as a cleaner product of animal feeding and prevention environmental pollution. Alternative feeding method may be helpful to utilize the innovative feeds and alternative protein feeds can contribute to ecological poultry production which has important function under certified organic standards (Fanatico et al., 2018). Also, nutrient strategies should be integrated into total production systems so that animal production systems are environmentally safe as well as economically viable (Lu et al., 2017). 
Table 2. Possible strategies to prevent the food loss and waste (FLW) at different stages of food supply chain (FSC) (Ishangulyyev et al., 2019)

\begin{tabular}{|c|c|}
\hline Stage & Strategy \\
\hline \multirow{5}{*}{ Production stage } & Government investments in infrastructure \\
\hline & Improve harvesting techniques \\
\hline & Improve market access \\
\hline & Organize extension services and educate farmers \\
\hline & Increase tax incentives for donating unsellable edible foods \\
\hline \multirow{5}{*}{ Handling and Storage Stage } & Improve transportation facilities \\
\hline & Provide access to cheap handling and storage technologies \\
\hline & Invest in storage facilities (warehouse, cold storage, etc.) \\
\hline & Improve the ability and knowledge of workers to employ safe food handling practice \\
\hline & Use of appropriate and clean containers for the products \\
\hline \multirow{9}{*}{$\begin{array}{l}\text { Processing and Packaging } \\
\text { Stage }\end{array}$} & Improve capacity of process line \\
\hline & Improve packaging to keep food fresher for longer \\
\hline & Standardize date labels to prevent consumer confusion \\
\hline & Establish other ways to use peels and trimmings \\
\hline & Improve the knowledge and ability of workers \\
\hline & Facilitate sanitary and cleaning inspections \\
\hline & Improve inventory systems \\
\hline & Establish online marketplaces to facilitate sale (donation) of perishable products \\
\hline & Change food date labeling practices and in-store promotions \\
\hline \multirow{6}{*}{$\begin{array}{l}\text { Distribution and Marketing } \\
\text { Stage }\end{array}$} & Improve institutions related to this stage \\
\hline & Improve transportation vehicles \\
\hline & Provide guidance on storage and preparation of food to consumers \\
\hline & Improve the knowledge and ability of workers \\
\hline & Improve market places (storage, covered areas) \\
\hline & Interlink with research institutions to predict consumer demand changes \\
\hline \multirow{10}{*}{ Consumption Stage } & Facilitate increased donation of unsold foods from cafeterias and restaurants \\
\hline & Implement consumer education and campaigns, both nationally and regionally \\
\hline & Reduced portion sizes \\
\hline & Provide education about hone economics in education institutions and communities \\
\hline & Involve women in food safe campaigns \\
\hline & Effective use of leftovers \\
\hline & $\begin{array}{l}\text { Training for restaurant, cafeteria, and supermarket management to forecast customer } \\
\text { demand and reflect demand in food purchasing to avoid bulk purchases }\end{array}$ \\
\hline & Implement good storage practices \\
\hline & Correctly interpret label dates \\
\hline & Distribution of excess food to charitable groups \\
\hline
\end{tabular}

Increased information is required to remedy the public's lack of awareness and concern regarding waste issues (Minghua et al., 2009). The barriers such as consumer and industry support, policy change and investment in food waste collection infrastructure should be overcome to use food waste in animal feed industry which may lead to substantial environmental and health benefits (Salemdeeb et al., 2017). Truong et al. (2019) proposed that food waste, occurring in all sectors of the food supply chain, could become a partial substitute for corn and soy in broiler diets. Akankali and Nwafili (2015) reported that the use of organic waste provide not only cheap alternative source of fish feed but also eliminates the problems associated with indiscriminate dumping of organic waste in the environment because of the associated air, water and soil pollution, and proper utilization of organic waste can contribute significantly to increasing fish productivity by 
reducing feed cost; protect the environment and reduction of greenhouse gas emissions. Shurson (2020) concluded that the tremendous opportunity for nitrogen and phosphorus resource recovery along with several other environmental benefits from recycling food waste streams and rendered animal by-products into animal feed have not been fully appreciated for their substantial contribution toward solving the climate crisis. Poultry industry itself generates large amounts of waste, and three primary waste products are dissolved air flotation sludge, compost from dead birds and hatchery waste, and litter and manure from production facilities which can be converted to feed and fertilizers (Brandelli et al.2015). Pourbayramian et al. (2021) identified potential applications of both potato wastes and rumen fluids; they have reported up to $78.8 \%$ digestion rates for potato waste and found that the solid parts of the fermentation mixture had the higher protein content. Tropical byproducts proposed for silage for pig feedstuff are spent grain, banana stems, banana skin (ripe), rejected banana (ripe), cassava leaves, cassava roots, molasses, breadfruit (ripe fruit), taro leaves, taro roots, sweet potato (leaves), sweet potato (tuber), yam (leaves), yam (root, olive cake, olive leaves, grape marc, sugar beet pulp, tomato pulp, wheat bran, date palm fruit and citrus pulp. In 2016, the amount of waste agricultural and forestry fibers is 2.02 billion tons in China; among them, 1.078 billion tons belong to waste agricultural fibers and 0.924 billion tons belongs to waste forestry fibers, and the main five utilization of waste agricultural and forestry fiber are energy utilization mode, the second one is material utilization mode, the third one is fertilizer utilization mode, the fourth one is feed utilization mode, and the fifth one is the cultivation-based utilization mode (Yunjuan et al., 2018). Wang et al. (2017) on the basis of primary data collected in 2016 from 100 villages across five provinces in China, reported that the proportion of villages with waste collection, waste transportation, and waste disposal services in 2015 is $80 \%, 55 \%$, and 22\%, respectively; and the differences in shares of villages with these services across provinces were statistically significant. They have proposed increase investments in waste collection facilities and worker services, encouraging local residents to classify and recycle waste; designing optimal waste transportation networks and routes; and improving on-site waste disposal technology. Zhou et al. (2017) reported that the adoption of resources use policy, industrial $\mathrm{SO}_{2}$ emission, local environmental regulation, GDP per capita, population density and educational level also affect industrial solid waste disposal, and it is important for China to continue implementing solid waste disposal policies, upgrade current industrial systems, push forward economic and social reform and increase environmental education to boost the effectiveness of solid waste disposal for long-term sustainable development. National environmental protection plant is indicated in Table 3.

Table 3. National environmental protection plants (Zhou et al., 2017)

\begin{tabular}{|l|c|}
\hline \multicolumn{1}{|c|}{ Year } & Solid Waste Policies and Plants \\
\hline 2003 & The 11th Five-Year Plan (11th FYP) \\
\hline 2009 & The 12 ${ }^{\text {th }}$ Five-Year Plan (12th FYP) \\
\hline 2009 & National Total Emission Control (NTEC) \\
\hline 2011 & National Environmental Protection “12th Five-Year Plan” \\
\hline 2015 & Solid Waste Pollution Preventing and Control Law (Revised Version) \\
\hline
\end{tabular}

\section{Public Awareness}

The amount of agricultural organic and urban waste has increased steadily in China. Waste management also addresses the use of multidisciplinary approaches ranging from engineering, humanities, sociology and biology. Almasi et al. (2019) stated that females with academic education and public employment as well as young females with academic education and public employment as well as young females had a great knowledge and practice, while they had less satisfaction with the waste collection systems. Almasi et al. (2019) concluded that with more emphasis on educational aspects, especially through municipalities and by creating participatory and encouraging programs among the families and the municipality, it is possible to improve the practice of citizens by improving their knowledge, while taking effective steps for promoting the environmental activity. 
Knickmeyer (2020) concluded that understanding social factors influencing household behavior is utmost importance; public education and specific communication highly contribute to improve recycling. Joshi and Visvanthan (2019) found that policies rather than technologies are driving food waste management efforts in Asia. Lang et al. (2020) reported that in Gansu province in China, 37.33\% of respondents has a high awareness and $62.67 \%$ of them has a low awareness of food waste recycling, which shows owners have a low level of overall awareness, and compared with the male restaurant owner, the female one has a lower awareness, and the younger restaurant owner has a higher awareness than the older one. Lang et al. (2020) found that factors, including the educational level of restaurant owner, restaurant scale, amount of daily restaurant food waste, the way of food waste treatment, and the macroeconomic development of Gansu city where restaurants located, have positive impacts on the awareness.

\section{Conclusions}

The main agriculture productions of China are rice, wheat, corn, beans and potatoes, there are some livestock- sheep, pork and cattle and so on. The occurrence of agricultural wastes was incredible in different regions with various climatic conditions. The agricultural straw and livestock excrement are considered to be potential resources. Improper disposition of agricultural wastes not only result in environmental pollution, but also waste a lot of valuable biomass resources in different areas. The recycling and utilization of agricultural wastes are categorized as the important step in environmental protection, agricultural development and energy structure. But, the most important problem in recycling agricultural section in China impeded the achievement of scale ecological functions. China is a traditional agricultural country with notable amounts of poultry farms, crops and etc. With the development of agriculture in China, the productions of straw and livestock manure grow significantly. It lacks laws and regulations of agricultural wastes recycling. The agricultural wastes from rapid expansion of animal farms and mushroom industries as well as other agricultural industries enter the environment. Improper disposition of agricultural wastes both result in environmental pollution and also waste a lot of valuable biomass resources. However, the crucial resources characteristics, utilization technologies, influence factors and socio-economic assessment on agricultural waste utilization still remain unclear. The development mode and operation mechanism of agricultural waste recycling can be discussed and elaborated systematically. Meanwhile, the perspective of collaborative innovation can also be explored via farmers, technical departments, professional associations and property management. In modern agronomic process, the small-scale recycling utilization could not afford the amounts of agricultural waste produced rapidly. They have suggested building economy incentive standard, improving laws and regulations, and creating rural market strengthening medium and long-term plans of agricultural waste recycling. Also, the influencing factors on the recycling and utilization of agricultural wastes have become the difficult problem in most countries, and the recycling and utilization policy of agricultural wastes should be considered via government attention and investment. There are some treatment methods for straw waste: fertilize; solid befouls; feeding the livestock; building or paper material and straw ethanol or diesel.

When it comes to organic waste, the mainly agricultural organic waste is the animal manure; spoiled feed; fodder vegetable etc., agricultural organic waste cannot be used as fertilizer directly, and they also can pollute the air, soil and water if they do not be treated. But, if loading organic waste into special containers and overlaps the access of air, they can produce a valuable energy raw material biogas. The gas is discharged into the gas storage and can be used as fuel. The biogas slurry and biogas residue are high quality fertile for the soil, and they also contribute to the increase in yield of some crops. The technology and the special containers need a little higher cost and the fuel are cheaper for farmers and companies, so the biogas just be used in some region in China. The plastic waste is the most difficult for China. Every year, there are millions of plastic bottle, plastic bag and plastic film be used in agriculture industry, but there are very few recycle places and recycle companies for them. 
As a result of rapid economic development coupled with the increasing urbanization and labor costs, the recycling rate of organic materials in Chinese agriculture has dramatically declined during the last two decades, in particular in the more developed eastern and southeastern provinces of China. Improper managing and storage of the organic wastes lead to severe air and water pollution. China has set goals for recycling farm waste such as crop stalks and plastic film, according to a policy document jointly released by the National Development and Reform Commission, Ministry of Agriculture. Biogas technology, which can help save on electrical costs, is too expensive for many farmers unless the government helps. Getting rid of animal waste is a major problem for livestock producers worldwide, especially because of the strong odor and damage caused to the atmosphere by the release of harmful gases. Another problem is run-off containing animal wastes can also seep into the water table, rivers and lakes. In China, how to better dispose of animal waste has become a particular problem due to the fast growth of poultry and hog farming over the past decade to meet demand for higher quality meat. China meets increasingly serious solid waste problems and has adopted various policies in response in recent years; meanwhile, few studies have investigated the performance of solid waste disposal through statistical analysis with empirical data. Composting is an aerobic proves under the thermophilic condition for transforming organic matter into nutrient-enriched compost; aeration and moisture content play a significant role in maintaining the thermophilic compost. Important factors that need to be considered for successful utilization of a food waste-based products are governmental framework, public participation, utilization of waste products, cost to process wastes, assessment of waste sources, and processing facilities. Setting national goals, awareness-raising campaigns, strict and appropriate regulation, stakeholder engagement, biorefinery and food waste recycling to animal feed are important strategies for better waste management. The most important food waste management practices in China are source separation, animal feed, rendering, composting, co-digestion, anaerobic digestion, incineration, landfill, and etc. Increase attitude towards food waste, awareness of food waste, and improve social norm on food waste, may lead to increase motivation to reduce and avoid food waste.

\section{Authors' Contributions}

All authors read and approved the final manuscript.

\section{Acknowledgements}

This research received no specific grant from any funding agency in the public, commercial, or not-forprofit sectors.

\section{Conflict of Interests}

The authors declare that there are no conflicts of interest related to this article.

\section{References}

Akankali JA, Nwafili SA (2015). Management of organic waste impacts on the environment: Utilization as fish feed. International Journal of Sustainable Development 4(5):513-528.

Alibardi L, Astrup TF, Asunis F, Clarke WP, De Gioannis G, Dessi P, ... Spiga D (2020). Organic waste biorefineries: Looking towards implementation. Waste Management 114:274-286. https://doi.org./10.1016/j.wasman.2020.07.010 
Almasi A, Mohammadi M, Azizi A, Berizi Z, Shamsi K, Shahbazi A, Mosavi SA (2019). Assessing the knowledge, attitude and practice of the Kermanshahi women towards reducing, recycling and reusing of municipal solid waste. Resources Conservation and Recycling 141:329-338. https://doi.org/10.1016/j.resconrec.2018.10.017

Ayilara MS, Olanreqaju OS, Babalola OO, Odeyemi O (2020). Waste management through composting: Challenges and potentials. Sustainability 12(4456):1-23. https://doi.org/10.3390/su12114456

Ayuso M, Pascual JA, Garcia C, Hernandez T (1996). Evaluation of urban wastes for agricultural use. Soil Science and Plant Nutrition 42(1):105-111. https://doi.org/10.1080/00380768.1996.10414693

Bekchanov M, Mirzabaev A (2018). Circular economy of composting in Sri Lanka: Opportunities and challenges for reducing waste related pollution and improving soil health. Journal of Cleaner Production 202:1107-1119. https://doi.org/10.1016/j.clepro.2018.08.186

Boulet M, Wright B, Williams C, Rickinson M (2019). Return to sender: a behavioural approach to reducing food waste in schools. Australasian Journal of Environmental Management 26(4): 328-346.

Brandelli A, Sala L, Kalil SJ (2015). Microbial enzymes for bioconversion of poultry waste into added-value products. Food Research International 73:3-12. https://doi.org/10.1080/14486563.2019.1672587

Brink N (1994). Composting of food waste, waste paper and milk carton, and cultivation in ready compost. Acta Agriculturae Scandinavica, Section B- Soil \& Plant Science 44(3):184-192. https://doi.org/10.1080/0906471940910243

Chen T, Jin Y, Qiu X, Chen X (2015). A study of the impact of moist-heat and dry-heat treatment processes on hazardous trace elements migration in food waste. Journal of Air and Waste Management Association 65(3):278-286. https://doi.org/10.1080/10962247.2014.990117

Chia WY, Chew KW, Le CF, Lam SS, Chee CSC, Ooi MSL, Show PL (2020). Sustainable utilization of biowaste compost for renewable energy and soil amendments. Environmental Pollution 267:115662. https://doi.org/10.1016/j.envpol.2020.115662

Corato UD (2020). Agricultural waste recycling in horticultural intensive farming systems by on-farm composting and compost-based tea application improves soil quality and plant health: A review under the perspective of a circular economy. Science of The Total Environment 738:139840. https://doi.org/10.1016/j.scitotenv.2020.139840

Davies AR, Legg R (2018). Fare sharing: interrogating the nexus of ICT, urban food sharing, and sustainability. Food Culture and Society 21(2):233-254. https://doi.org/10.1080/15528014.2018.1427924

Dhanya BS, Mishra A, Chandel AK, Verma ML (2020). Development of sustainable approached for converting the organic waste to bioenergy. Science of The Total Environment 723:138109. https://doi.org/10.1016/j.scitotenv.2020.138109

Doctor WA, Mahmoud IB, Masmoudi S, Triki MA, Mounier S, Ammar E (2020). Physico-chemical and spectroscopic quality assessment of compost from date palm (Phoenix dactylifera L.) waste valorization. Journal of Environmental Management 264:110492. https://doi.org/10.1016/j.jenvman.2020.110492

Donovan SM, Bateson T, Gronow JR, Voulvoulis N (2010). Characterization of compost-like outputs from mechanical biological treatment of municipal solid waste. Journal of Air and Waste Management Association 60(6):694-701. https://doi.org/10.3155/1047-3289-60.6.694

Duan Y, Pandey A, Zhang Z, Awasthi MK, Bhatia SK, Taherzadeh MJ (2020). Organic solid waste biorefinery: Sustainable strategy for emerging circular bioeconomy in China. Industrial Crops and Products 153:112568. https://doi.org/10.1016/j.indcrop.2020.112568

Dusoruth V, Peterson HH, Schmitt J (2018). Estimating a local food waste baseline. Journal of Food Products Marketing 24(5):654-680. https://doi.org/10.1080/10454446.2018.1472698

Fanatico AC, Arsi K, Upadhyaya I, Morales Ramos J, Donoghue D, Donogue AM (2018). Sustainable fish and invertebrate meals for methionine and protein feeds in organic poultry production. Journal of Applied Poultry Research 27(4):437-448. https://doi.org/10.3382/japr/pfy037

Ferreira S, Cabral M, da Cruz NF, Simoes P, Marques RC (2017). The costs and benefits of packaging waste management systems in Europe: The perspective of local authorities. Journal of Environmental Planning Management 60:773791. https://doi.org/10.1080/09640568.2016.1181609

Galsim F, Golabi MH, Kim YS, Iyekar C (2020). Comparative effects of composted organic waste and inorganic fertilizer on nitrate leachate from the farm soils of northern Guam. International Soil and Water Conservation Research. https://doi.org/10.1016/j.iswcr.2020.09.003 
Ghosh PR, Fawcett D, Sharma SB, Poinern GEJ (2016). Progress towards sustainability utilization and management food wastes in the global economy. International Journal of Food Science 22:3563478. https://doi.org/10.1155/2016/3563478

Gryta A, Frac M, Oszust K (2019). Community shift in structure and functions across soil profile in response to organic waste and mineral fertilization strategies. Applied Soil Ecology 143:55-60. https://doi.org/10.1016/j.apsoil.2019.05.032

Guo W, Zhou Y, Zhu N, Hu H, Shen W, Huang X, ... Li Z (2018). On site composting of food waste: A pilot scale case study in China. Resources Conservation and Recycling 132:130-138. https://doi.org/10.1016/j.rescpnrec.2018.01.033

Guo H-N, Wu S-B, Tian Y-J, Zhang J, Liu H-T (2021). Application of machine learning methods for the prediction of organic solid waste treatment and recycling processes: A review. Bioresource Technology 319:124114. https://doi.org/10.1016/j.biortech.2020.124114

Ilakovac B, Cerjak M, Voca N (2020). Why do we waste food? In-depth interviews with consumers. Energy Sources, Part A: Recovery, Utilization, Environmental Effects. https://doi.org/10.1080/15567036.2020. 1787564

Inaba T, Su T, Aoyagi T, Aizawa H, Sato Y, Suh C, ... Habe H (2020). Microbial community in an anaerobic membrane bioreactor and its performance in treating organic solid waste under controlled and deteriorated conditions. Journal of Environmental Management 269:110786. https://doi.org/10.3390/foods8080297

Ishangulyyev R, Kim S, Lee SH (2019). Understanding food loss and waste- Why are we losing and wasting food? Foods 8(297):1-23. https://doi.org/10.3390/foods8080297

Jara-Samaniego J, Moral MR, Perez-Murica D, Paredes C, Galvez-Sola L, Gavilanes-Teran I, Bustamante MA (2015). Urban waste management and potential agricultural use in South American developing countries: A case study of Chimborazo region (Ecuador). Communications in Soil Science and Plant Analysis 46:157-169. https://doi.org/10.1080/00103624.2014.988587

Jeevahan J, Anderson A, Sriram V, Durairaj RB, Joseph GB, Mageshwaran G (2018). Waste into energy conversion technologies and conversion of food wastes into the potential products: a review. International Journal of Ambient Energy. https://doi.org/10.1080/01430750.2018.1537939

Joshi P, Visvanathan C (2019). Sustainable management practices of food waste in Asia: Technological and policy drivers. Journal of Environmental Management 247:538-550. https://doi.org/10.1016/j.jenvman.2019.06.079

Kakadellis S, Harris ZM (2020). Don not scrap the waste: The need for broader system boundaries in bioplastic food packaging life-cycle assessment - A critical review. Journal of Cleaner Production 274:122831. https://doi.org/10.1016/j.jclepro.2020.122831

Kan I, Ayalon O, Federman R (2010). On the efficiency of composting organic wastes. Agricultural Economics 41(2):151163. https://doi.org/10.1111/j.1574-0862.2009.00432.x

Kaudal BB, Weatherley AJ (2018). Agronomic effectiveness of urban biochar aged through co-composting with food waste. Waste Management 77:87-97. https://doi.org/10.1016/j.wasman.2018.04.042

Kazemi-Bonchenari M, Alizadeh AR, Javadi L, Zohrevand M, OdongoNE, Salem AZM (2017). Use of poultry precooked slaughterhouse waste as ruminant feed to prevent environmental pollution. Journal of Cleaner Production 145:151-156. https://doi.org/10.1016/j.jclepro.2017.01.066

Kelley TR, Walker PM, Smiciklas KD (1999). Research article: survival of culturable bacteria during co-composting of institutional, agricultural, and municipal solid wastes. Environmental Practice 1(3):162-167. https://doi.org/10.1017/s1466046600000600

Knickmeyer D (2020). Social factors influencing household waste separation: A literature review on good practices to improve the recycling performance of urban areas. Journal of Cleaner Production 245:118605. https://doi.org/10.1016/j.jclepro.2019.118605

Kucbel M, Raclavska H, Ruzickova J, SvedovaB, Sassmanova V, Drozdova J, ... Juchelkova D (2019). Properties of composts from household food waste produced in automatic composters. Journal of Environmental Management 236:657-666. https://doi.org/10.1016/j.jenvman.2019.02.018

Lang L, Wang Y, Chen X, Zhang Z, Yang N, Xue B, Han W (2020). Awareness of food waste recycling in restaurants: evidence from China. Resources, Conservation and Recycling 161:104949. https://doi.org/10.1016/j.resconrec.2020.104949

Leung DYC, Wang J (2016). An overview on biogas generation from anaerobic digestion of food waste. International Journal of Green Energy 13(2):119-131. 
Li Y, Jin Y, Li J, Chen Y, Gong Y, Li Y, Zhang J (2016). Current situation and development of kitchen waste treatment in China. Procedia Environmental Sciences 31:40-49. https://doi.org/10.1016/j.proenv.2016.02.006

Lin H, Ye J, Sun W, Yu Q, Wang Q, Zou P, ... Ma J (2020). Solar composting greenhouse for organic waste treatment in fed-batch mode: Physiochemical and microbiological dynamics. Waste Management 113:1-11. https://doi.org/10.1016/j.wasman.2020.05.025

Liu K-M, Lin S-H, Hsieh J-C, Tzeng G-H (2018). Improving the food waste composting facilities site selection for sustainable development using a hybrid modified MADM model. Waste Management 75:44-59. https://doi.org/10.1016/j.wasman.2018.02.017

Lu L, Liao X-D, Luo X-G (2017). Nutritional strategies for reducing nitrogen, phosphorus and trace mineral excretions of livestock and poultry. Journal of Integrative Agriculture 16(12):2815-2833. https://doi.org/10.1016/s2095$3119(17) 61701-5$

Mahjoub B, Domscheit E (2020). Changes and challenges of an organic waste-based bioeconomy. Current Opinion in Green and Sustainable Chemistry 25:100388. https://doi.org/10.1016/j.cogsc.2020.100388

Mandpe A, Paliya S, Kumar S, Kumar R (2019). Fly ash as an additive for enhancing microbial and enzymatic activities in in-vessel composting of organic wastes. Bioresource Technology 293:122047. https://doi.org/10.1016/j.biortech.2019.122047

Mansfield B, Mendes W (2013). Municipal food strategies and integrated approaches to urban agriculture: Exploring three cases from the global North. International Planning Studies 18(1):37-60. https://doi.org/10.1080/13563475.2013.750942

Margaritis M, PsarrasK, Panaretou V, Thanos AG, Malamis D, Sotiropoulos A (2018). Improvement of home composting process of food waste using different minerals. Waste Management 73:87-100. https://doi.org/10.1016/j.wasman.2017.12.009

Milinkovic M, Lalevic B, Jovicic-Petrovic J, Golubovic-Curguz V, Kljujev I, Raicevic V (2019). Biopotential of compost and compost products derived from horticultural waste - Effect on plant growth and plant pathogens' suppression. Process Safety and Environmental Protection 121:299-306. https://doi.org/10.1016/j.psep.2018.09.024

Minghua Z, Xiumin F, Rovetta A, Qichang H, Vicentini F, BingkaiL, ... Yi L (2009). Municipal solid waste management in Pudong New Area, China. Waste Management 29:1227-1233. https://doi.org/10.1016/j.wasman.2008.07.016

Moldagulova N, AyupovaA, Sembayeva D, Duambekov M, Khassenova E, Nagyzbekkyzy E, ... Sarsenova A (2020). Data on the isolation and identification of thermotolerant microorganisms from cow manure promising for organic waste processing. Data in Brief 31:105761. https://doi.org/10.1016/j.dib.2020.105761

Nigussie A, Kuyper TW, Neergaard AD (2015). Agricultural waste utilization strategies and demand for urban waste compost: Evidence from smallholder farmers in Ethiopia. Waste Management 44:82-93. https://doi.org/10.1016/j.wasman.2015.07.038

Pai S, Ai N, Zheng J (2019). Decentralized community composting feasibility analysis for residential food waste: A Chicago case study. Sustainable Cities and Society 50:101683. https://doi.org/10.1016/j.scs.2019.101683

Papa G, Sciarria TP, Carrara A, Scaglia B, D’Imporzano G, Adani F (2020). Implementing polyhydroxyalkanoates production to anaerobic digestion or organic fraction of municipal solid waste to diversify products and increase total energy recovery. Bioresource Technology 318:124270. https://doi.org/10.1016/j.biortech,2020.124270

Pereira RF, Cardoso EJBN, Oliveira FC, Estrada-Bonilla GA, Cerri CEP (2018). A novel way of assessing C dynamics during urban organic waste composting and greenhouse gas emissions in tropical region. Bioresource Technology Reports 3:35-42. https://doi.org/10.1016/j.biteb.2018.02.002

Pickering GJ, Pickering HMG, Northcotte A, Habermebl C (2020). Participation in residential organic waste diversion programs: Motivators and optimizing educational messaging. Resources, Conservation and Recycling 158:104807. https://doi.org/10.1016/j.resconrec.2020.104807

Pourbayramian R, Abdi-Benemar H, Seifdavati J, Greiner R, Elghandour MMMY, Salem AZM (2021). Bioconversion of potato waste by rumen fluid from slaughterhouses to produce a potential feed additive rich in volatile fatty acids for farm animals. Journal of Cleaner Production 280(1):124411. https://doi.org/10.1016/j.jclepro.2020.124411

Rada EC, Zatelli C, Mattolin P (2014). Municipal solid waste selective collection and tourism. Waste Management and The Environment VII 180:187-197. https://doi.org/10.2495/wm140161

Ranieri E, Montanaro C, Ranieri AC, Campanaro V, Cioca LI (2017). Municipal solid wastes in the South-Eastern Mediterranean region: Quality, quantity, and management quality. Quality - Access to Success 18:162-169.

Rastogi M, Nandal M, Khosla B (2020). Microbes as vital additives for solid waste composting. Heliyon 6:e03343. https://doi.org/10.1016/j.heliyon.2020.e03343 
Salah E, Hala O (2017). Sustainable and cost-effective use of organic waste. Current Trends in Biomedical Engineering and Biosciences 7(4):555719. https://doi.org/10.19080/ctbeb.2017.07.555719

Salemdeeb R, zuErmgassen EKHJ, Kim MH, Balmford A, Al-Tabbaa A (2017). Environmental and health impacts of using food waste as animal feed: A comparative analysis of food waste management options. Journal of Cleaner Production 140:871-880. https://doi.org/10.1016/j.jclepro.2016.05.049

Schulz R, Romheld V (1997). Recycling of municipal and industrial organic wastes in agriculture: Benefits, limitations and means of improvement. Soil Science and Plant Nutrition 43(1):1051-1056. https://doi.org/10.1080/00380768.1997.11863716

Shahrajabian MH, Soleymani A (2017). Responses of physiological indices of forage sorghum under different plant populations in various nitrogen fertilizer. International Journal of Plant and Soil Science 15(2):1-8. https://doi.org/10.9734/ijpss/2017/32460

Shahrajabian MH, Sun W, Cheng Q (2019). Measures to achieve a stable farming system in sustainable agriculture- a short review. Annales Universitatis Paedagogicae Cracoviensis Studia Naturae 4(4):172-181. https://doi.org/10.24917/25438832.4.11

Shahrajabian MH, Khoshkharam M, Sun W, Cheng Q (2020). The impact of manganese sulfate on increasing grain yield, protein and manganese content of wheat cultivars in semi arid region. Journal of Stress Physiology and Biochemistry 16(1):76-79.

Sharma D, Yadav KD (2018). Application of rotary in-vessel composting and analytical hierarchy process for the selection of a suitable combination of flower waste. Geology, Ecology, and Landscapes 2(2):137-147. https://doi.org/10.1080/24749508.2018.1456851

Shurson GC (2020). What a waste- Can we improve sustainability of food animal production systems by recycling food waste streams into animal feed in an era of health, climate, and economic crises? Sustainability 12:7071. https://doi.org/10.3390/su12177071

Small G, Sisombath B, ReussL, Henry R, Kay A (2017). Assessing how the ration of barley mash to wood chips in compost affects rates of microbial processing and subsequent vegetable yield. Compost Science and Utilization 25(4):272281. https://doi.org/10.1080/1065657x.2017.1329038

Slorach PC, Jeswani HK, Cuellar-Franca R, Azapagic A (2020). Environmental sustainability in the food-energy-waterhealth nexus: A new methodology and an application to food waste in a circular economy. Waste Management 113:359-368. https://doi.org/10.1016/j.wasman.2020.06.012

Soleymani A, Shahrajabian MH, Khoshkharam M (2016). The impact of barley residue management and tillage on forage maize. Romanian Agricultural Research 33:161-167. https://doi.org/10.2478/cerce-2019-0003

Soleymani A, Shahrajabian MH (2017). Effects of planting dates and row distance on sugar content, root yield and solar radiation absorption in sugar beet at different plant densities. Romanian Agricultural Research 34:1-11. https://doi.org/10.23880/oajar-16000105

Srivastava RK, Shetti NP, Reddy KR, Aminabhavi TM (2020). Sustainable energy from waste organic matters via efficient microbial process. Science of The Total Environment 722:137927. https://doi.org/10.1016/j.scitotenv.2020.137927

Sullivan DM, Fransen SC, Bary AI, Cogger CG (1998). Fertilizer nitrogen replacement value of food residuals composted with yard trimmings, paper or wood wastes. Compost Science and Utilization 6(1):6-18. https://doi.org/10.1080/1065657X.1998.10701904

Sullivan DM, Bary AI, Nartea TJ, Myrhe CG, Fransen SC (2003). Nitrogen availability seven years after a high-rate food waste compost application. Compost Science and Utilization 11(3):265-275. https://doi.org/10.1080/1065657x.2003,10702133

Sun Y, Chen SS, Lau AYT, Tsang DCW, Mohanty SK, Bhatnagar A, ... Ok YS (2020). Waste-derived compost and biochar amendments for stormwater treatment in bioretention column: Co-transport of metals and colloids. Journal of Hazardous Materials 383:121243. https://doi.org/10.1016/j.jhazmat.2019.121243

Sun W, Shahrajabian MH, Cheng Q (2020a). Barberry (Berberis vulgaris), a medicinal fruit and food with traditional and modern pharmaceutical uses. Israel Journal of Plant Sciences 68(1-2):1-11. https://doi.org/10.1163/22238980bja10019

Sun W, Shahrajabian MH, Cheng Q (2020b). Fenugreek cultivation with emphasis on historical aspects and its uses in traditional medicine and modern pharmaceutical science. Mini Reviews in Medicinal Chemistry 21(6):724-730. https://doi.org/10.2174/1389557520666201127104907 
Takata M, Fukushima K, Kino-Kimata N, NagaoN, Niwa C, Toda T (2012). The effects of recycling loops in food waste management in Japan: Based on the environmental and economic evaluation of food recycling. Science of The Total Environment 432:309-317. https://doi.org/10.1016/j.scitotenv.2012.05.049

Toledo M, Marquez P, Siles JA, Chica AF, Martin MA (2019). Co-composting of sewage sludge and eggplant waste at full scale: Feasibility study to valorize eggplant waste and minimize the odoriferous impact of sewage sludge. Journal of Environmental Management 247:205-213. https://doi.org/10.1016/j.jenvman.2019.06.076

Tonini D, Wandl A, Meister K, Unceta PM, Taelman SE, Sanjuan-Delmas D, ... Huygens D (2020). Quantitative sustainability assessment of household food waste management in the Amsterdam Metropolitan Area. Resources, Conservation Recycling 160:104854. https://doi.org/10.1016/j.resconrec.2020.104854

Truong L, Morash D, Liu Y, King A (2019). Food waste in animal feed with a focus on use for broilers. International Journal of Recycling Organic Waste Agriculture 8:417-429. https://doi.org/10.1007/s40093-019-0276-4

Tseng W-L, Chiueh P-T (2015). Urban metabolism of recycling and reusing food waste: A case study in Taipei city. Procedia Engineering 118:992-999. https://doi.org/10.1016/j.proeng.2015.08.540

Tucker CA, Farrelly T (2016). Household food waste: the implications of consumer of choice in food from purchase to disposal. Local Environment 21(6):682-706. https://doi.org/10.1080/13549839.2015.1015972

Tufvesson LM, Lantz M, Borjesson P (2013). Environmental performance of biogas produced from industrial residues including competition with animal feed-life cycle calculations according to different methodologies and standards. Journal of Cleaner Production 53:214-223. https://doi.org/10.1016/j.jlepro.2013.04.005

Vandermeersch T, Alvarenga RAF, Ragaert P, Dewulf J (2014). Environmental sustainability assessment of food waste $\begin{array}{lllll}\text { valorization } & \text { options. } & \text { Resource } & \text { Conservation }\end{array}$ https://doi.org/10.1016/j.resconrec.2014.03.008

Vico A, Perez-Muica MD, Bustamante MA, Agullo E, Marhuenda-Egea FC, Saez JA, ... Moral R (2018). Valorization of date palm (Phoenix dactylifera L.) pruning biomass by co-composting with urban and agri-food sludge. Journal of Environmental Management 226: 408-415. https://doi.org/10.1016/j.jenvman.2018.08.035

Voberkova S, Maxianova A, Schlosserova N, Adamcova D, Vrsanska M, Richtera L, ... Vaverkova MD (2020). Food waste composting- Is it really so simple as stated in scientific literature? - A case study. Science of The Total Environment 723:138202. https://doi.org/10.1016/j.scitotenv.2020.138202

Wainaina S, Awasthi MK, Sarsaiya S, Chen H, Singh E, Kumar A, ... Taherzadeh MJ (2020). Resource recovery and circular economy from organic solid waste using aerobic and anaerobic digestion technologies. Bioresource Technology 301:122778. https://doi.org/10.1016/j.biortech.2020.122778

Wang H, Nie Y (2001). Municipal solid waste characteristics and management in China. Journal of Air and Waste Management Association 51(2):250-263. https://doi.org/10.1080/10473289.2001.10464266

Wang A, Zhang L, Shi Y, Rozelle S, Osborn A, Yang M (2017). Rural solid waste management in China: Status, problems and challenges. Sustainability 9(506):1-18. https://doi.org/10.3390/su9040506

Wang X, Selvam A, Lau SSS, Wong JWC (2018). Influence of lime and struvite on microbial community succession and odour emission during food waste composting. Bioresour Technol 247:652-659. https://doi.org/10.1016/j.biortech.2017.07.091

Warshawsky DN (2020). The limits of food waste governance in cities: Case study of Dyton, Ohio. Geographical Review. https://doi.org/10.1080/00167428.2020.1776124

Zhao Y, Liu J, Lin T, Zhao Q, Lin M, Xing L, ... Ye H (2019). Urban-rural nitrogen emission from household food consumption in China: spatial pattern and dynamics analysis. International Journal of Sustainable Development and World Ecology 26(5):415-427. https://doi.org/10.1080/13504509.2019.1581851

Yu Z, Zhang Y-C, Zhang X, Wang Y (2015). Conversion of food waste into biofertilizer for the biocontrol of root knot nematode by Paecilomy seslilacinus. Environmental Technology 36(24):3148-3158. https://doi.org/10.1080/09593330.2015.1055817

Yunjuan S, Jianchun J, Junli L, Hao Y (2018). Present utilization conditions of waste agricultural and forestry fiber in China. Advances in Biotechnology and Microbiology 11(5):555825. https://juniperpublishers.com/aibm/pdf/AIBM.MS.ID.555825.pdf

Zhou Y, Selvam A, Wong JWC (2016). Effect of Chinese medicinal herbal residues on microbial community succession and anti-pathogenic properties during co-composting with food waste. Bioresource Technology 217:190-199. https://doi.org/10.1016/j.biortech.2016.03.080

Zhou B, Sun C, Yi H (2017). Solid waste disposal in Chinese cities: An evaluation of local performance. Sustainability 9:2234. https://doi.org/10.3390/su9122234 
Zhou Y, Selvam A, Wong JWC (2018). Chinese medicinal herbal residues as a bulking agent for food waste composting. Bioresource Technology 249:182-188. https://doi.org/10.1016/j.biortech.2017.09.212

Zhu C, Fan R, Luo M, Lin J, Zhang Y (2020). Urban food waste management with multi-agent participation: A combination of evolutionary game and system dynamics approach. Journal of Cleaner Production. 275:123937. https://doi.org/10.1016/j.jclepro.2020.123937
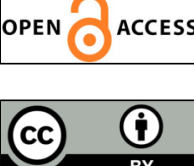

The journal offers free, immediate, and unrestricted access to peer-reviewed research and scholarly work. Users are allowed to read, download, copy, distribute, print, search, or link to the full texts of the articles, or use them for any other lawful purpose, without asking prior permission from the publisher or the author.

License - Articles published in Notulae Scientia Biologicae are Open-Access, distributed under the terms and conditions of the Creative Commons Attribution (CC BY 4.0) License.

(c) Articles by the authors; SHST, Cluj-Napoca, Romania. The journal allows the author(s) to hold the copyright/to retain publishing rights without restriction. 